\title{
The Influence of Teacher Competence and Motivation on The Teacher's Performance of SMP Negeri 11 Palembang
}

\author{
Melany Sandriyani ${ }^{1 *}$, Happy Fitria ${ }^{2}$, Achmad Wahidy $^{2}$ \\ ${ }^{I}$ SMP Negeril1 Palembang, South of Sumatera, Indonesia \\ ${ }^{2}$ Universitas PGRI Palembang, Indonesia \\ *Corresponding author. Email: mami.melanys@gmail.com
}

\begin{abstract}
The purpose of this study is to assess and characterize the effect of competence and motivation on teacher performance at SMP Negeri 11 Palembang. The participants in this study were 60 professors from SMP Negeri 11 Palembang. Quantitative methods are used in this research. One of the data collection tools is a questionnaire with a Likert scale and 5 alternative answer choices. SPSS version 25.0 was used to analyze the data. The instrument was subjected to a validity and reliability test, and the data analysis method was multiple linear regression, $\mathrm{T}$ test (partial), $\mathrm{F}$ test, and the coefficient of determination (R2). Based on the study findings, the following conclusions can be drawn: (1) there is a major impact between teacher competence and teacher performance. (2) Teacher motivation has a significant impact on teacher performance, and (3) teacher skills and motivation together have a significant influence on teacher performance.
\end{abstract}

Keywords: Competence, Motivation and Teacher Performance

\section{INTRODUCTION}

Education is critical to human civilization and the advancement of a nation. As required by Law No.20 of 2003 [1] on the National Education System, the government, in this case the Minister of National Education, has started a movement to improve educational quality that national education serves to improve the skill and form the character and civilization of a dignified nation in order to educate the life of the nation that aims to develop learners' potential to become human beings who believe in God Almighty, have a noble character, are healthy, competent, capable, imaginative, and self-sufficient, and who want to become a democratic and responsible citizen.

The professional competence of teachers is one of the important factors in improving teacher performance. The competencies required of teachers include pedagogical competencies, personality competencies, social competencies, and professional competencies gained through professional education [2]. The four fields are interconnected, have an impact on one another, and have a hierarchical relationship. Professional teachers have a social responsibility manifested through the competence of teachers from social environment and have effective interactive skills [3].
Teacher certification, as part of an effort to improve teacher quality, is expected to increase teachers' achievement in carrying out their duties and responsibilities as teachers in their subjects. The teacher certification program has been in place since 2007, following the issuance of The Ministry of National Education Regulation No. 18 of 2007 on Certification for Teachers in Office. This certification program is designed to improve teachers' skills as professional educators.

In addition, teacher work motivation also occupies an important factor in influencing teacher performance [4]. Work motivation is something that can generate the spirit or encouragement of working individuals or groups towards work in order to achieve goals. Furthermore, the teacher will demonstrate an interest in carrying out a task or event and then do it well if there is a motivating force, namely motivation [5]. Motivation also plays a very important role in increasing student's achievement [6]

Because teachers have the most direct contact with students in the educational process in school institutions, the quality of teacher performance has a significant impact on the quality of educational outcomes [7]. 
Based on the results of initial observations conducted by researchers at SMP Negeri 11 Palembang. The researchers found indicators that there are some problems regarding the competencies of teachers, it is shown that there are still often teachers who are late in the classroom for the learning process. From the observation of the learning process is still found teachers who do not master the teaching material, using ways of learning that are not in accordance with the applicable curriculum, the absence of administrative preparation in the learning process, as teachers have not mastered technology-based facilities, the presence of teachers who have not used a variety of learning models so that the learning process takes place monotonously, there are teachers who do not carry out evaluations to learners and there are still teachers who have not been able to create effective learning.

On this basis, this study will investigate the impact of teacher competence and motivation on teaching performance, specifically at SMP Negeri 11 Palembang.

\section{METHODS}

From July 2020 to December 2020, this study was carried out at This study's samples were all professors from SMP Negeri 11 Palembang, South Sumatra Province.

If the subject has fewer than 100 people, include them all in the study to make it a population study [8]. If the subject is big or has more than 100 individuals, it can be taken at a rate of $10-15 \%, 20-20 \%$, or higher. Based on the preceding, it is possible to infer that the sample in this study is a complete sample, which means that all populations are sampled because the population is less than 100 individuals. The participants in this study were all professors at SMP Negeri 11 Palembang.

To begin, a questionnaire is a data collection method that involves asking respondents a series of questions and providing them with written statements for [9]. The questionnaire used in this study was of the option type, with checklist marks assigned based on the answers directly given to respondents. This was done with consideration to limit the answers of respondents so as not to deviate from the discussion of questionnaires. The questionnaire contains statements related to research variables that will be distributed to respondents in accordance with the predetermined sample. Each questionnaire amounted to 25 statements for work motivation, 25 statements for work discipline variables and 25 questions for teacher performance.

Validity test statements will be re-tested at SMP Negeri 11 Palembang with 60 respondents.

Both observations are a technique or way of collecting data by way of conducting observations on ongoing activities [10]. This observation becomes one of the data collection techniques if in accordance with the purposes of the research planned and recorded systematically so that the research can run as desired. The aim of this study is to discover the competence and motivation of teachers toward the performance of teachers at SMP Negeri 11 Palembang.

Third, documentation is a method of gathering data and information in the form of books, archives, memos, writing numbers, and photographs in the form of reports and information that can be used to support [10]. The documentation used to collect data is then scrutinized. The documentation approach was used in this study to determine the number of teachers, the list of teachers present, and an overview of SMP Negeri 11 Palembang.

\section{RESULTS AND DISCUSSION}

\section{1). Effect of Competence on Performance (Partial Hypothesis)}

The regression coefficient is often referred to as partial hypothesis testing or testing the influence of each independent variable on a dependent variable or testing the influence of a competency variable $\left(\mathrm{X}_{1}\right)$ on a performance variable (Y) and a teacher motivation variable $\left(\mathrm{X}_{2}\right)$ on teacher performance variable $(\mathrm{Y})$ by examining the $t$ value on the current output. The results of the tests are shown in the table below.

Table 1: Results of Statistical Analysis Test $t$

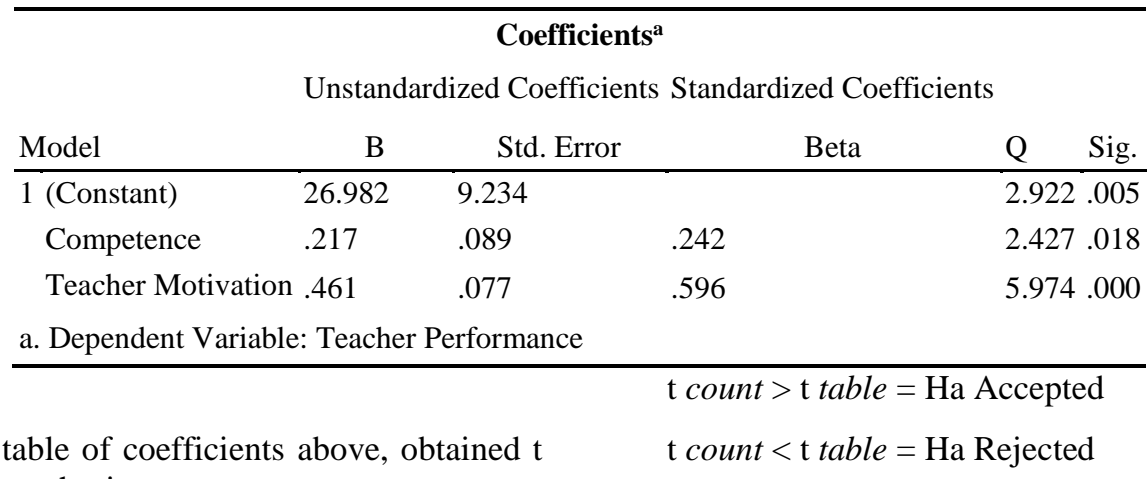

Based on the table of coefficients above, obtained $t$ count of 2,427. Hypothesis test: 
specifying t table $=\mathrm{t}$ table searched on $=5 \%: 2=$ 2.5 percent (2-sided test) with n-k-1 degrees of freedom (df) or $60-2-1=57$ ( $\mathrm{n}$ is the number of samples and $\mathrm{k}$ is the number of independent variables). The results for the tablet of 2,002 were obtained using a two-sided test (significance $=0.025$ ). Based on the explanation above in know $\mathrm{t}$ count $=2,427$ and $\mathrm{t}$ table $=2,002$ where $\mathrm{t}$ count $>\mathrm{t}$ table meaning Ha received or in other words partially there is an influence competence on performance.

\section{2) Testing of regression variable teacher motivation coefficient against performance}

Based on the table of coefficients above, obtained t count of 5,974

Hypothesis test:

$\mathrm{t}$ count $>\mathrm{t}$ table $=$ Ha Accepted

$\mathrm{t}$ count $<\mathrm{t}$ table $=$ Ha Rejected

specifying $\mathrm{t}$ table $=\mathrm{t}$ table searched on $=5 \%: 2=2.5$ percent (2-sided test) with n-k-1 degrees of freedom (df) or $60-2-1=57$ ( $\mathrm{n}$ is the number of samples and $\mathrm{k}$ is the number of independent variables). The result for the $t$ table of 2,002 was obtained using a two-sided test (significance $=0.025)$. Based on the explanation above in know $t$ count $=5,974$ and $t$ table $=2,002$ where $t$ count $>t$ table which means Ha received or in other words partially there is an influence of teacher motivation on performance. Regression equation based on table 4.12(coefficients) are as follows.

$$
\begin{aligned}
& \mathrm{Y}=26,982+0.217 \mathrm{X}_{1}+0.461 \mathrm{X}_{2} \\
& \mathrm{Y}=\text { Performance } \\
& \mathrm{X}_{1}=\text { Competency } \\
& \mathrm{X}_{2}=\text { Teacher Motivation }
\end{aligned}
$$

3) Influence of Competence and Motivation on Performance (Simultaneous Hypothesis)

This test is used to determine whether the regression coefficient is positive or negative has a significant influence or not jointly between independent variables $\left(\mathrm{X}_{1}\right.$ and $\left.\mathrm{X}_{2}\right)$ on dependent variables (Y). If Sig. $>\alpha$ $(0.05)$, the regression coefficient is insignificant. If Sig. $<\alpha(0.05)$, then the regression coefficient is significant. Multiple correlation analysis is often referred to as

\begin{tabular}{|c|c|c|c|c|c|}
\hline \multicolumn{6}{|c|}{ ANOVA $^{b}$} \\
\hline Model & Sum of Squares & Df & Mean Square & $\mathrm{F}$ & Sig. \\
\hline 1 Regression & 3673.997 & 2 & 1836.998 & 33.366 & $.000^{\mathrm{a}}$ \\
\hline Residual & 3138.187 & 57 & 55.056 & & \\
\hline Total & 6812.183 & 59 & & & \\
\hline \multicolumn{6}{|c|}{ a. Predictors: (Constant), Teacher Motivation, Competence } \\
\hline
\end{tabular}
simultaneous hypothesis or f-test test shown in the table below.

Table 2: F Test Statistical Analysis Results

Based on $f$ count in the table above in know 33,366

Hypothesis test:

$$
\begin{aligned}
& \mathrm{f} \text { count }>\mathrm{f} \text { table }=\text { Ha Accepted } \\
& \mathrm{f} \text { count }<\mathrm{f} \text { table }=\text { Ha Rejected }
\end{aligned}
$$

Based on the explanation above in know $f$ count $=$ 33,366 and ftable3.16where $f$ count $>f$ table which means Ha received or in other words there is influence competence and motivation of teachers on performance.

\section{CONCLUSION}

It can be gathered as follows based on the results of data analysis: 1) consider the impact of competence on teacher performance at SMP Negeri 11 Palembang; 2) the effect of teacher motivation on the performance of teachers at SMP Negeri 11 Palembang. The results of the $\mathrm{T}$ Test calculation using SPSS calculation version 25.0 show the calculation of these two variables, and 3 ) the calculation of Test F using SPSS calculation version 25.0 shows that competence and motivation have a major impact on the performance of teachers at SMP Negeri 11 Palembang.

\section{REFERENCES}

[1] Law on Teachers and Lecturers, Law No. 14 of 2005.

[2] Arafat, Yasir., Damayani, T., \& Eddy, S. (2020). The Influence of Principal Leadership and Work Motivation on Performance. Ejournal.karinoseff.org/index.php/jitim/article/vie w/29 (November 6, 2020, 10:16pm) 
[3] Bimayu, W., Kristiawan, M., \& Fitriani, Y. (2020). The Effect of Emotional Intelligence, Student's Motivation toward Student's Achievement. International Journal of Progressive Sciences and Technologies (IJPSAT), 20(1), 06-16.

[4] Kompri. (2016). Motivasi pembelajaran perspektif guru dan siswa [Motivation for learning from the perspective of teachers and students]. Bandung: $\mathrm{PT}$ Remaja Rosda karya.

[5] Darmiati, D., Kristiawan, M., \& Rohana, R. (2020). The Influence of School Leadership and Work Motivation toward Teacher's Discipline. Journal of Social Work and Science Education, 1(1), 32-44. Retrieved from https://ejournal.karinosseff.org/index.php/jswse/arti cle/view/8

[6] Fitria, H., Kristiawan, M., \& Rahmat, N. (2019). Upaya Meningkatkan Kompetensi Guru Melalui Pelatihan Penelitian Tindakan Kelas [Efforts to Improve Teacher Competence through Classroom Action Research Training]. ABDIMAS UNWAHAS, 4(1).

[7] Suharsaputra, U. (2013). Education Administration. Bandung. Refika Aditana.

[8] Fitria, Happy (2020). The Influence of Work Environment and Work Motivation on High School Performance in Muara Padang Subdistrict. http://jurnal.radenfatah.ac.id/index.php/intelektualit a/article/view/564

[9] Arikunto, S (2010). Research Management New Edition. Jakarta. Rineka Cipta.

[10] Sugiyono. (2016). Educational Research Methods. Bandung. Pt. Teen Rosda Works 